\title{
MINERAIS ESTRATÉGICOS E AS RELAÇÕES ENTRE BRASIL E CHINA: OPORTUNIDADES DE COOPERAÇÃO PARA O DESENVOLVIMENTO DA INDÚSTRIA MINERAL BRASILEIRA
}

\author{
Fernando Ferreira de Castro ${ }^{1}$ \\ Carlos Cesar Peiter ${ }^{2}$ \\ Geraldo Sandoval Góes 3
}

\begin{abstract}
As matérias-primas minerais são a base da economia atual e continuarão a ser no futuro. Certas matérias-primas apresentam especificidades, porque tanto o risco de suprimento como a sua importância econômica variam entre os países ou blocos econômicos, sendo definidas como "criticas", por propiciarem incertezas em seus mercados. No âmbito da relevância mundial dos bens minerais, este artigo tem o objetivo de discutir aspectos das diferentes políticas sobre os minerais críticos e/ou estratégicos, adotadas no Brasil, bem como na União Europeia, Estados Unidos, China, que foram selecionados por terem posição de destaque neste tema e serem os principais destinos de exportações primárias brasileiras. Além disso, diante da crescente importância da relação Brasil-China, esta relação bilateral será avaliada à luz das recentes políticas sobre os recursos minerais apresentadas, focalizando o caso do nióbio brasileiro, que é uma matéria-prima crítica para os países consumidores e estratégica para o Brasil, maior produtor mundial. A metodologia qualitativa adotada parte de extensa revisão bibliográfica e documental no contexto da geopolítica das matérias-primas, para classificar as diferentes políticas nacionais e avaliar as complementariedades sino-brasileiras neste cenário. As relações entre Brasil e China quanto aos bens minerais estratégicos e críticos sugerem desafios e oportunidades de ampliação de parcerias por meio da ciência, tecnologia e inovação (CT\&l) e estímulo ao desenvolvimento industrial.
\end{abstract}

Palavras-chave: minerais estratégicos; matérias-primas críticas; nióbio; CT\&l; comércio sino-brasileiro.

\section{STRATEGIC MINERALS AND BRAZIL-CHINA RELATIONS: OPPORTUNITIES FOR COOPERATION FOR THE DEVELOPMENT OF THE BRAZILIAN MINERAL INDUSTRY}

\begin{abstract}
Mineral raw materials are the basis of the current economy and will continue to be so in the future. Certain raw materials have specificities due to supply risks and economic importance that vary among countries or economic blocs, being defined as "critical" for providing uncertainties in their markets. In the context of the global relevance of mineral goods, this article aims to discuss aspects of different policies on critical and / or strategic minerals, adopted by the European Union, United States, China and Brazil. They were selected for having a prominent position in this issue and being the main destinations of Brazilian primary exports, and, in addition, it is observed a
\end{abstract}

\footnotetext{
1. Pesquisador do Centro de Tecnologia Mineral do Ministério da Ciência, Tecnologia e Inovações (Cetem/MCTI). Mestre em psicossociologia. E-mail: <fcastro@cetem.gov.br>. Orcid: <https://orcid.org/0000-0002-5144-4862>.

2. Pesquisador Colaborador do Cetem/MCTI. Doutor em engenharia mineral, engenheiro metalúrgico. E-mail:<cpeiter@cetem.gov.br>. Orcid: <https://orcid.org/0000-0002-5557-1519>.

3. Especialista em políticas públicas e gestão governamental na Diretoria de Estudos e Políticas Macroeconômicas (Dimac) do Ipea. Doutor em economia. E-mail: <geraldo.goes@ipea.gov.br>. Orcid:<https://orcid.org/0000-0002-5367-8654>.
} 
growing importance of the Brazil-China relationship. To evaluate this bilateral relationship in the light of the recent policies on the assessed mineral resources, we will focus in the case of Brazilian niobium, which is a critical raw material for consumer countries and it is strategic for Brazil, the world's larger producer. The qualitative methodology adopted is part of an extensive bibliographic and documentary review in the context of the geopolitics of raw materials, to classify the different national policies and evaluate the Sino-Brazilian complementarities in this scenario. The relations between Brazil and China on the issue of strategic and critical mineral goods suggest challenges and opportunities for expanding partnerships through Science, Technology and Innovation and stimulating industrial development.

Keywords: Strategic minerals; critical raw materials; niobium; ST\&l; China-Brazil trade.

\section{MINERALES ESTRATÉGICOS Y RELACIONES ENTRE BRASIL Y CHINA: OPORTUNIDADES DE COOPERACIÓN PARA EL DESARROLLO DE LA INDUSTRIA MINERA BRASILEÑA}

Las materias primas minerales son la base de la economía actual y lo seguirán siendo en el futuro. Ciertas materias primas tienen especificidades porque tanto el riesgo de oferta como su importancia económica varían entre países o bloques económicos, siendo definidas como "críticas" porque brindan incertidumbres en sus mercados. En el ámbito de la relevancia global de los bienes minerales, este artículo tiene como objetivo discutir aspectos de las diferentes políticas sobre minerales críticos y / o estratégicos, adoptadas en la Unión Europea, Estados Unidos, China y Brasil, las cuales fueron seleccionadas por tener una posición destacada en este tema y serán los principales destinos de las exportaciones primarias brasileñas, y, además, dada la importancia creciente de la relación Brasil-China, esta relación bilateral será a la luz de las políticas recientes sobre los recursos minerales evaluados, centrándose en el caso del niobio brasileño, que es una materia prima crítica para los países consumidores y estratégica para Brasil, el mayor productor mundial. La metodología cualitativa adoptada es parte de una extensa revisión bibliográfica y documental en el contexto de la geopolítica de las materias primas, para clasificar las diferentes políticas nacionales y evaluar las complementariedades de Brasil en este escenario. Las relaciones entre Brasil y China en el tema de bienes minerales estratégicos y críticos sugieren desafíos y oportunidades para ampliar las alianzas a través de la ciencia, la tecnología y la innovación y el estímulo del desarrollo industrial.

Palabras clave: minerales estratégicos; materias primas críticas; nióbio; CT\&l; Comercio China-Brasil.

JEL: L71;L72.

DOI: http://dx.doi.org/10.38116/rtm24art12

Data de envio do artigo: 31/8/2020. Data de aceite: 16/11/2020.

\section{INTRODUÇÃO}

As matérias-primas minerais são a base da economia atual e continuarão a ser no futuro (IRTC, 2020). Os bens minerais não energéticos fazem parte de todas as indústrias em algum estágio de suas cadeias produtivas, tornando-se cada vez mais essenciais para alavancar mudanças, como as tecnologias digitais, as tecnologias de baixo carbono e a mobilidade sustentável (EC, 2019). 
Embora ainda abundantes, a garantia de seu fornecimento envolve pesquisa, investimento e constante inovação (USGS, 2017). Certas matérias-primas apresentam especificidades, porque tanto o risco de suprimento como a sua importância econômica variam entre os países ou blocos econômicos, e vêm sendo definidas como "criticas", por apresentarem incertezas em seus mercados (EC, 2018; Fortier et al., 2018).

No âmbito da relevância mundial dos bens minerais, este artigo tem os objetivo de: i) apresentar aspectos das políticas internacionais sobre os minerais críticos e/ou estratégicos adotadas recentemente nos Estados Unidos, União Europeia e China, que são os principais países consumidores ou destino das exportações minerais brasileiras, além do próprio Brasil; e ii) diante da crescente importância das relaçóes comerciais Brasil-China no mercado internacional de commodities, avaliar esta relação bilateral e suas repercussōes sobre os recursos minerais. Por fim, será discutido o caso do nióbio brasileiro, que é uma matéria-prima crítica para os países consumidores e estratégica para o Brasil, maior produtor mundial, e sua relação com a China, maior inovador nas aplicaçôes do nióbio. As relaçôes entre Brasil e China na interface dos bens minerais sugerem desafios e oportunidades por meio da ciência, tecnologia e inovação (CT\&I).

\section{SETOR MINERAL BRASILEIRO E AS RELAÇÕES COMERCIAIS COM A CHINA}

O Brasil é reconhecido líder produtor e participante do mercado global de commodities minerais, em especial de minerais metálicos. Entre esses, se destacam o minério de ferro, o cobre, o ouro, o alumínio e o nióbio. Com base nos dados disponíveis no Anuário Mineral Brasileiro (AMB) de 2019 (ano base 2018), o valor total de exportaçōes das principaissubstânciasmetálicasbrasileirastotalizouUS $\$ 46,44$ bilhóes (ANM, 2020). O principal destino das exportaçōes minerais brasileiras é a China, responsável por $27,7 \%$ do valor total exportado (US\$12,85 bilhóes), seguida pelos Estados Unidos, com 12,9\% (US\$ 6,02 bilhôes). Entre os bens minerais mais exportados para a China, estão as substâncias metálicas ferro, nióbio, cobre, manganês, níquel, alumínio, zinco, cromo e estanho (tabela 1).

TABELA 1

Comércio internacional de substâncias metálicas entre China e Brasil (US\$ FOB)

\begin{tabular}{lccc}
\hline & Brasil - total & Brasil-China & Participação (\%) \\
\hline Exportações & 46.443 .673 .172 & 12.852 .933 .221 & 27,67 \\
Importações & 11.314 .048 .667 & 2.035 .515 .996 & 17,99 \\
\hline
\end{tabular}

Fonte: Ministério da Economia; ANM (2019).

Obs.: $\mathrm{FOB}=$ free on board. 
A figura 1 ilustra os principais países destinatários das exportaçôes brasileiras dos principais bens minerais metálicos em 2018. Destaca-se a variedade de bens e o valor das exportaçóes brasileiras; além da China, conforme apresentado, os Estados Unidos importam o equivalente a US\$ 6,02 bilhóes, principalmente em ferro, nióbio, vanádio, estanho, manganês, alumínio, cromo, cobre e zinco, ao passo que a União Europeia importa as mesmas variedades de minerais metálicos, totalizando US\$2,99 bilhóes, e o Canadá (US\$ 2,07 bilhóes) e a Argentina (US\$ 1,80 bilhão) também se destacam pela importação destas substâncias e do ouro.

\section{FIGURA 1}

Destino das exportações brasileiras referentes aos principais minerais metálicos (2018)

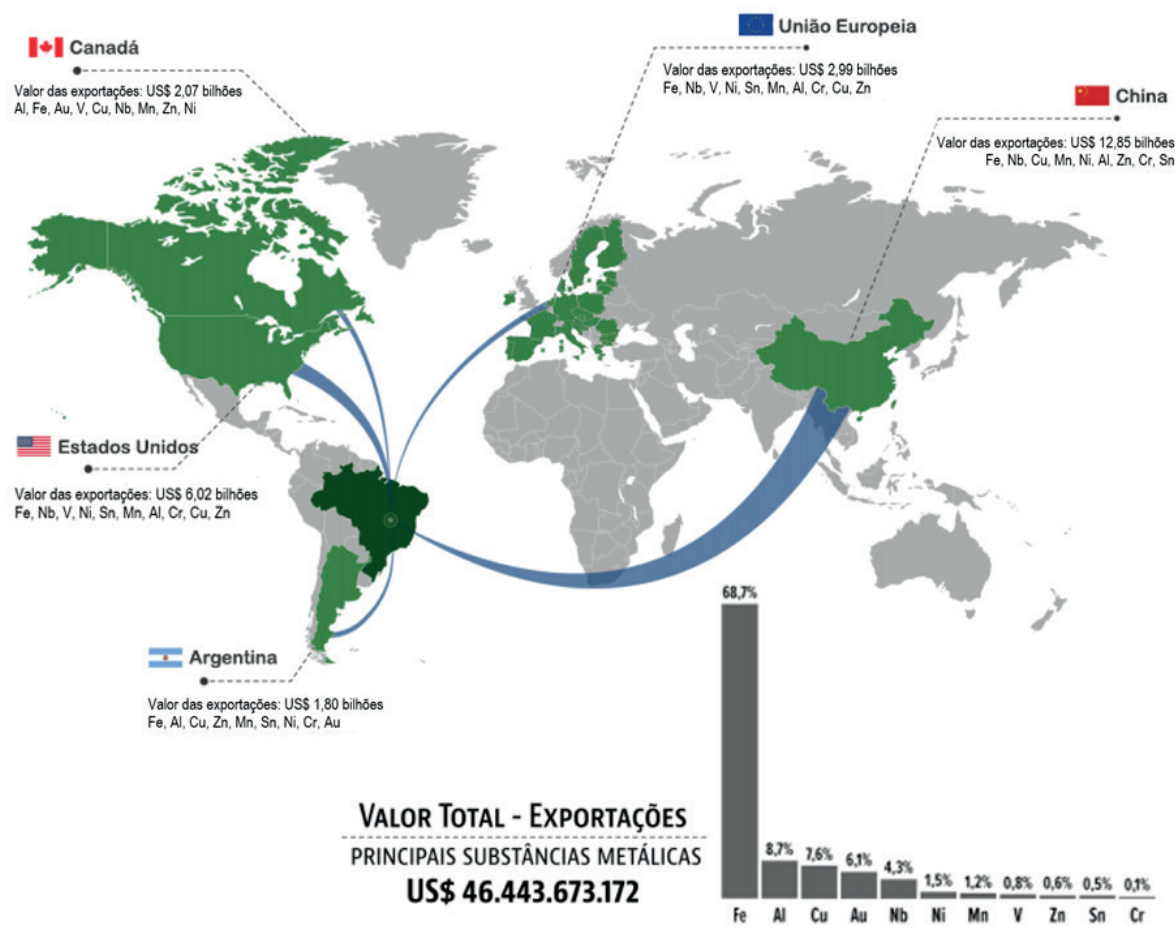

Fonte: Adaptado de ANM (2020).

Elaboração dos autores.

Obs.: Figura reproduzida em baixa resolução em virtude das condições técnicas dos originais (nota do Editorial).

$\mathrm{Na}$ relação Brasil-China, o Brasil se apresenta como um grande produtor e exportador de bens primários e semimanufaturados eimportador de manufaturados chineses, tal como apresentado na tabela 2. Destaca-se, no comércio exterior, o saldo comercial positivo para o Brasil (tabela 3). 
TABELA 2

Balança do comércio exterior brasileiro para as principais substâncias metálicas em 2018 (US\$ FOB)

\begin{tabular}{|c|c|c|c|}
\hline & Exportação & Importação & Saldo comercial \\
\hline \multicolumn{4}{|l|}{ Brasil-Mundo } \\
\hline Bens primários & 23.572 .410 .418 & 1.041.217.241 & 22.531 .193 .177 \\
\hline Semimanufaturados & 15.224 .787 .818 & 3.118 .414 .712 & 12.106 .373 .106 \\
\hline Manufaturados & 6.974 .733 .995 & 6.881 .476 .389 & 93.257 .606 \\
\hline Compostos químicos & 671.740 .941 & 272.940 .325 & 398.800 .616 \\
\hline Total & 46.443 .673 .172 & 11.314 .048 .667 & 35.129 .624 .505 \\
\hline \multicolumn{4}{|l|}{ Brasil-China } \\
\hline Bens primários & 11.524 .490 .790 & 15.974 .950 & 11.508 .515 .840 \\
\hline Semimanufaturados & 1.280 .795 .738 & 74.262 .705 & 1.206 .533 .033 \\
\hline Manufaturados & 40.994 .241 & 1.901 .533 .576 & -1.860 .539 .335 \\
\hline Compostos químicos & 6.652 .452 & 43.744 .765 & -37.092 .313 \\
\hline Total & 12.852 .933 .221 & 2.035.515.996 & 10.817 .417 .225 \\
\hline
\end{tabular}

A característica marcante da presença do Brasil no comércio internacional é a sua condiçâo de exportador de commodities minerais, principalmente de bens primários, enquanto a China tem se especializado na produção e fornecimento de produtos manufaturados de origem mineral, essenciais para inúmeras aplicaçôes, com destaque para as tecnologias emergentes nas áreas de energia, eletroeletrônicos, transportes e equipamentos hospitalares.

O comércio do minério de ferro brasileiro com a China, liderado pela empresa Vale S/A, é o mais importante em valor, quantidade produzida e exportada, com uma participação de $84,74 \%$ na produção de minério de ferro, cujo valor total das exportaçóes brasileiras totalizaram $\mathrm{R} \$ 31,92$ bilhôes em 2018 , o que representa 68,74\% das exportações de minerais metálicos (ANM, 2020).

A concentração da produção e do fornecimento de substâncias minerais em determinados países ricos em recursos do subsolo tem influenciado a geopolítica internacional no sentido de definiçóes sobre as matérias-primas consideradas críticas, bem como a adoção de estratégias comerciais e industriais pelos países e blocos econômicos. Documentos da Uniăo Europeia e dos Estados Unidos (Fortier et al., 2018; EC, 2017; USGS, 2015) apontam a relevância da China como a principal fonte de suprimento de matérias-primas minerais consideradas críticas, tal como pode ser observado na figura 2 . 
FIGURA 2

Oferta de matérias-primas críticas segundo principais países fornecedores (Em \%)

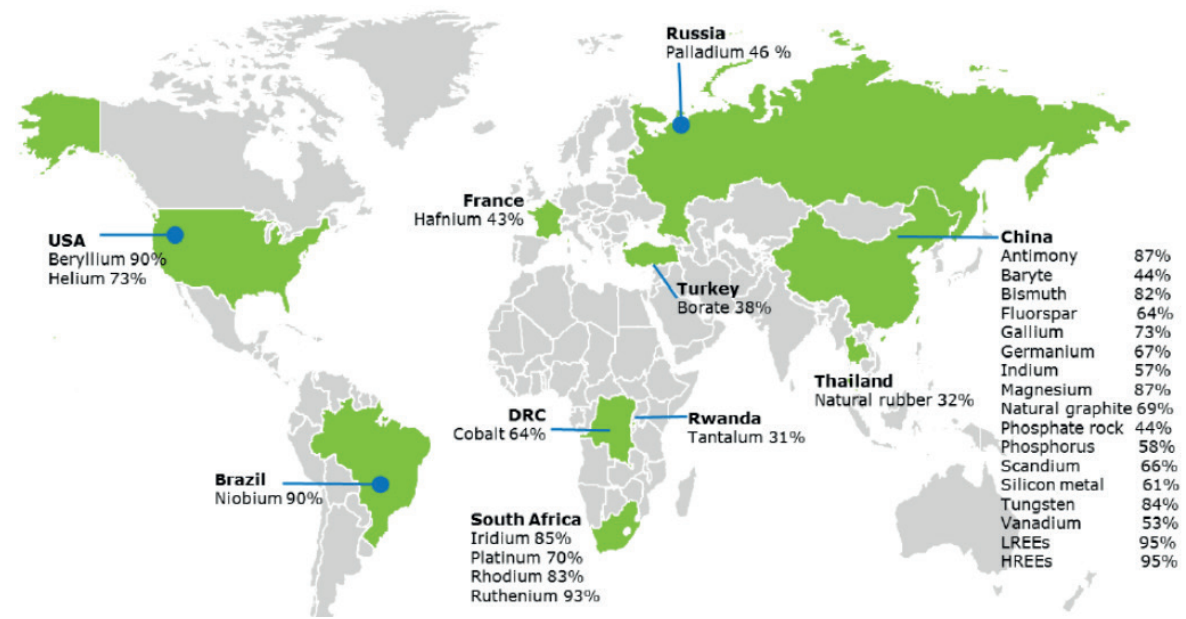

Fonte: Deloitte Sustainability et al. (2017).

Obs.: Figura reproduzida em baixa resolução em virtude das condições técnicas dos originais (nota do Editorial).

$\mathrm{Na}$ figura 2, além da predominância da China, verifica-se que o Brasil aparece como o principal produtor e fornecedor apenas de nióbio; entretanto, o Brasil certamente está entre os fornecedores mundiais de outras matérias-primas críticas, como o tântalo, o vanádio e o grafite natural (grafita). $O$ gráfico 1 apresenta a participação brasileira nas reservas minerais mundiais em exploração, e o gráfico 2 apresenta a participação do Brasil na produção mundial dos seus principais bens minerais.

GRÁFICO 1

Participação e posição do Brasil na classificação mundial das principais reservas minerais em exploração (2016)

(Em \%)

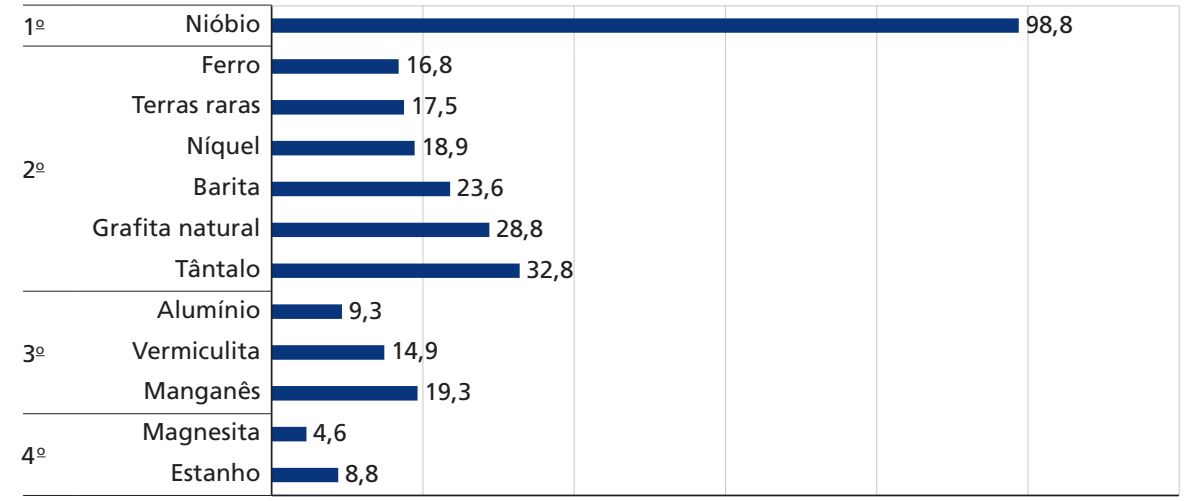


GRÁFICO 2

Participação e posição do Brasil na classificação mundial dos principais produtores mundiais de metálicos (2016)

(Em \%)

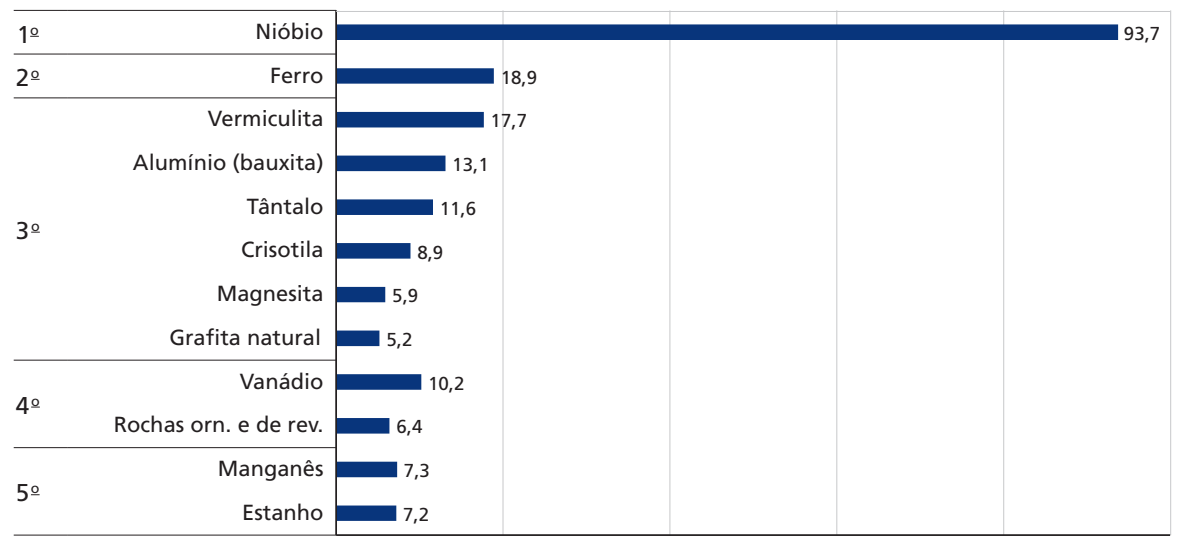

Fonte: ANM (2019).

A participação do Brasil na classificação mundial das principais reservas minerais é muito favorável, notadamente em relação ao nióbio, destacado em primeiro lugar, aparecendo em segundo lugar no mundo para tântalo, grafita natural, barita, níquel, terras raras e ferro. Em termos das reservas em produção, o Brasil também se sobressai em relação ao nióbio, em primeiro lugar, e ao ferro, em segundo lugar, assim como na produção de alumínio, vanádio e rochas ornamentais e de revestimento.

\section{METODOLOGIA E ANTECEDENTES DA PESQUISA}

A proposta deste artigo se originou do projeto intitulado "Estudo das cadeias produtivas dos materiais críticos: oportunidades e ameaças da economia circular"4 (Diálogos Setoriais UE-Brasil, 2020), desenvolvido por uma equipe multidisciplinar liderada pelo Cetem/MCTI, financiado pelo programa Diálogos Setoriais Uniáo Europeia-Brasil e pelo MCTI. Ao aprofundar o conhecimento sobre as políticas nacionais ou dos blocos de países sobre as matérias-primas, verificou-se a emergência da China como o mais importante player, não apenas no mercado internacional de commodities minerais, mas também na produçáo e comercializaçáo de especialidades minerais destinadas a produtos inovadores e com potencial crescente de mercado. Diante dessa posição de relevância da China, que ameaça o suprimento de países e blocos econômicos, novas políticas

4. 0 relatório técnico final do projeto está no prelo, e será publicado na página oficial de projetos do Diálogos Setoriais União Europeia-Brasil (projeto oํ 128-A - 9ª chamada), que poderá ser acessado em: <https://bit.ly/3bkujw0>. 
vêm sendo construídas para garantir a segurança no atendimento às suas indústrias e mercados. O estudo de caso do mencionado relatório é o nióbio, do qual o Brasil é o maior produtor mundial, tendo a China como grande parceira e investidora.

A metodologia qualitativa adotada envolveu revisão bibliográfica sobre o tema da geopolítica das matérias-primas e evolução do comércio exterior brasileiro sobre os bens minerais, bem como documental sobre as políticas internacionais de matérias-primas, tendo sido selecionadas as políticas da Uniâo Europeia, Estados Unidos e China, principais parceiros comerciais do Brasil. A análise dos documentos buscou identificar os principais interesses e estratégias adotadas pelos países, bem como o caso específico da complementariedade entre China e Brasil, especialmente no caso do nióbio, no contexto internacional de disputa por matérias-primas críticas.

Diante do panorama apresentado, é fundamental discutir o conceito de matérias-primas minerais críticas ou estratégicas que vem sendo desenvolvido principalmente pela União Europeia e Estados Unidos para avaliar a disponibilidade e o risco de suprimento de suas indústrias e sociedades. Na seção a seguir, serão apresentadas sinteticamente as principais características das políticas da União Europeia, Estados Unidos, China e Brasil sobre o tema.

\section{MATÉRIAS-PRIMAS CRÍTICAS OU ESTRATÉGICAS E AS POLÍTICAS NACIONAIS}

A preocupaçáo quanto ao risco no suprimento de minerais tem caracterizado os esforços de políticas internacionais promovidas por importantes instituiçóes em países industrializados, na contextualização dessa questão, como o United States Geological Survey (USGS) ("O crescimento econômico de uma nação industrializada (...) requer matérias-primas para construçáo (...), defesa, processamento e fabricação de bens e serviços" [USGS, 2019]); a Raw Materials Information Systems (RMIS) ("As matérias-primas são mais do que nunca a força vital da economia" [RMIS, 2015]); a British Geological Survey (BGS) ("A preocupação global é crescente quanto à disponibilidade de suprimentos segura e adequada de minerais e metais necessários à sociedade" [BGS, 2017]); a General Agreement on Tariffs and Trade da Organização Mundial do Comércio (GATT/WTO) ("O caso das matérias-primas chinesas coloca uma advertência para os países exportadores de matérias-primas quando negociam (...) sua soberania sobre os recursos naturais" [Rolland, 2012]).

As políticas nacionais, em diversos países, sobre as matérias-primas críticas são uma resposta ao aumento da competição comercial internacional para atender a inovaçóes tecnológicas, que ampliam oportunidades econômicas pela utilização de certos materiais com aplicaçôes específicas. As estratégias dos países sobre os minerais críticos procuram atender às peculiaridades e demandas domésticas identificadas através de políticas que direcionam os interesses econômicos, de defesa e até mesmo de saúde de cada país. 
Segundo Barteková e Kemp (2016), a estratégia da União Europeia busca interagir com os países considerados mais ricos em recursos minerais. O Japão e os Estados Unidos seguem a direção da pesquisa e do desenvolvimento de alternativas, enquanto a China e a Austrália se preocupam com a sua produção doméstica e a proteção dos seus recursos com políticas protecionistas. O Brasil dispóe de uma política sobre minerais estratégicos que focaliza a produção de minerais em que o país apresenta vantagem competitiva, naqueles cuja demanda tem sido crescente e na pesquisa por minerais portadores de desenvolvimento econômico no futuro. A seguir, serão apresentadas as características gerais das políticas sobre os minerais críticos da União Europeia, nos Estados Unidos, na China e no Brasil.

\subsection{União Europeia}

A Uniâo Europeia se destaca na abrangência das políticas públicas voltadas às matérias-primas críticas, devido ao seu histórico decrescimento e pouca disponibilidade de reservas domésticas de minerais metálicos (EC, 2008). O debate sobre a segurança de suprimento de matérias-primas se iniciou em 1975, e a União Europeia pode ser considerada um dos primeiros blocos de países a discutir as necessidades e desafios para seus países. Mais recentemente, a Uniấo Europeia vem promovendo a Raw Materials Initiative (EC, 2017), que busca: garantir o acesso a matérias-primas a partir do mercado internacional nas mesmas condiçóes que outros competidores industriais; determinar as condiçóes estruturais adequadas dentro do bloco, no sentido de promover o suprimento de matérias-primas a partir das fontes existentes nos países-membros; e impulsionar a eficiência dos recursos e da reciclagem para reduzir as necessidades de consumo de matérias-primas de fontes primárias, diminuindo também a sua dependência de importaçóes.

A União Europeia disponibiliza um sistema de informaçóes sobre as matérias-primas, intitulado Raw Materials Information System (RMIS). Entre os documentos disponíveis nesta plataforma, estão apresentadas orientaçóes para condução da temática e premissas metodológicas, além da base de dados sobre minerais críticos da União Europeia sob o ponto de vista de diversos aspectos, como os legislativos, tecnológicos, de monitoramento, de economia circular, de comércio, de cadeias produtivas industriais, entre outros (RMIS, 2015).

A metodologia de criticalidade da CE envolve tanto matérias-primas críticas bióticas, como abióticas, sendo o inventário composto por 78 matérias-primas, sem considerar as energéticas ou agriculturais, mas envolvendo os elementos de terras raras leves (light rare earth elements - LREE) e pesadas (heavy rare earth elements - HREE) e elementos do grupo platina (RMIS, 2017). As principais matérias-primas críticas da União Europeia estão apresentadas na tabela 3. 
TABELA 3

Matérias-primas críticas identificadas na lista da Comunidade Europeia (2017)

\begin{tabular}{lll}
\hline & Matérias-primas críticas - 2017 (26) & \\
\hline Antimônio & Háfnio & Grupo platina \\
Barita & Hélio & Rocha de fosfato \\
Berílio & Terras-raras (pesados) & Fósforo \\
Bismuto & Terras-raras (leves) & Escândio \\
Boro & Índio & Silício metal \\
Cobalto & Magnésio & Tântalo \\
Fluorita & Grafita natural & Tungstênio \\
Gálio & Borracha natural & Vanádio \\
Germânio & Nióbio & \\
\hline
\end{tabular}

Fonte: EC (2017).

Destaca-se que, entre alguns minerais que compóem a lista da União Europeia de matérias-primas críticas que são considerados com alto risco de suprimento, está o nióbio, cujas principais fontes se encontram no Brasil; os elementos de terras raras pesados e leves, antimônio, bismuto, tungstênio, magnésio, entre outros, provenientes principalmente da China; os metais do grupo da platina, predominantes na África do Sul; e o paládio, cujas maiores reservas em produção estão na Rússia.

No gráfico 3, está representado um estudo sobre a posição relativa das matérias-primas consideradas críticas, segundo os aspectos de risco de suprimento e importância econômica para o bloco europeu, com base em levantamentos sobre as reservas em produção das matérias-primas mundiais e no monitoramento permanente, em nível multidisciplinar, das cadeias produtivas industriais europeias (RMIS, 2017).

No gráfico 3, verifica-se uma correlação entre a importância econômica e o risco de suprimento de 73 substâncias minerais, entre as quais, em vermelho, estão destacadas as matérias-primas consideradas críticas. A partir deste inventário, podem ser elencados os diferentes níveis de preocupação e a definição de planos e açóes voltados para as matérias-primas com maior prioridade. A Uniấo Europeia se destaca internacionalmente, segundo Barteková e Kemp (2016), por basear a Raw Materials Initiative em três pilares de sustentação. 
GRÁFICO 3

Posição relativa das matérias-primas críticas segundo o risco de suprimento e importância econômica no ambiente europeu - CRM List (2017)

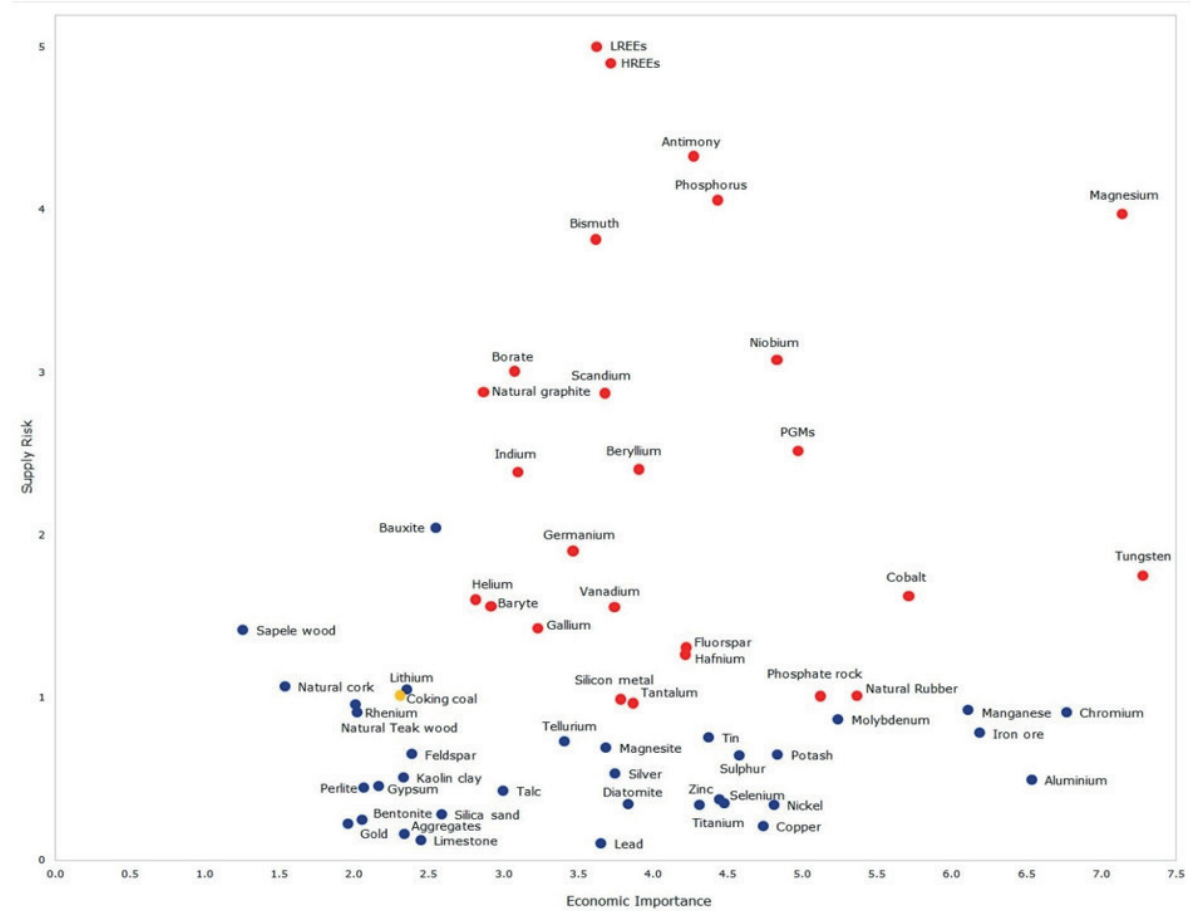

Fonte: RMIS (2017)

Obs.: Gráfico reproduzido em baixa resolução em virtude das condições técnicas dos originais (nota do Editorial).

O primeiro pilar tem como foco o acesso às matérias-primas no mercado mundial, evitando as possíveis distorçóes de mercado por meio de acordos diplomáticos e políticas de parceria com os interesses econômicos dos países ricos em recursos minerais. O segundo pilar da iniciativa almeja a construção de uma estrutura dentro do bloco para estimular a sustentabilidade das reservas europeias de matérias-primas, por intermédio da pesquisa e investimento em projetos de exploração em determinados países, como Suécia, Finlândia e Dinamarca (para o caso específico da Groenlândia). O terceiro pilar da iniciativa foca a redução do consumo primário de matérias-primas através da eficiência da produção, reciclagem, busca por materiais substitutos e investimento no uso de matérias-primas renováveis.

A política da CE para a implementação da economia circular tem grande ligação com o risco de suprimento e a demanda por materiais considerados críticos, como é o caso do nióbio brasileiro. O Plano de Ação para Economia Circular da $\mathrm{CE}$ estabelece as vinculações entre as matérias-primas críticas e as açôes previstas 
para uma abordagem eficiente e coerente da política, a partir de bancos de dados atualizados, a promoção de boas práticas e a identificação de possíveis ações futuras (EC, 2018).

\subsection{Estados Unidos}

Os Estados Unidos têm uma longa tradição no debate sobre o seu suprimento de matérias-primas, fortemente relacionado com seus interesses militares e de segurança nacional. Em 2018, a sua lista de minerais críticos foi atualizada por ordem do Gabinete da Presidência dos Estados Unidos, tendo sido elaborada por meio de subcomitê específico do National Science and Technology Council - o Subcomitê das Cadeias de Suprimento de Minerais Críticos e Estratégicos -, que utilizou metodologia própria de indicação dos minerais críticos (NSTC, 2018, tradução nossa).

"Mineral Crítico", como definido pela EO no 13.817 , é um mineral (1) identificado como não combustível mineral ou material mineral essencial para a segurança econômica e nacional dos Estados Unidos da América, (2) de uma rede de suprimentos que é vulnerável a ruptura, e (3) que serve como uma função essencial na manufatura de um determinado produto, cuja ausência (...) poderia gerar consequências substanciais para a economia e a segurança nacional norte-americana.

A USGS, principal agência de pesquisa geológica dos Estados Unidos, publica o anuário intitulado Mineral Commodities Summary, que apresenta um relatório concebido em conjunto com o Departamento de Defesa dos Estados Unidos para estimar a abrangência dos minerais não energéticos nas cadeias produtivas industriais americanas. Além da publicação anual, a USGS também disponibiliza uma base de dados contendo informaçôes da indústria doméstica, programas do governo, tarifas comerciais e aspectos sobre produção, comércio, importação e procedência de minerais críticos e estratégicos para a indústria americana (USGS, 2020).

Uma parceria entre distintos departamentos do governo dos Estados Unidos tem como foco a elaboração da lista dos minerais críticos para a nação, assim como os principais produtores e fornecedores, bem como as suas principais aplicaçóes na indústria estadunidense (conforme a tabela 4).

As preocupaçóes do governo dos Estados Unidos quanto à perda de sua capacidade produtiva e suas implicaçóes para a segurança nacional e industrial conduziram a elaboração da Critical Materials Strategy, em 2010, atualizado recentemente (2019). Esta política se sustenta em três pilares: a diversificação das cadeias de suprimento para administrar o risco de suprimento; direcionamento da pesquisa e desenvolvimento $(\mathrm{P} \& \mathrm{D})$ para a busca por materiais e tecnologias substitutivas; e investimento em pesquisas de processos de reciclagem, reuso e aproveitamento mais eficiente de minerais críticos (USDE, 2011). 
TABELA 4

Lista de elementos/minerais críticos para os Estados Unidos

\begin{tabular}{|c|c|c|c|c|c|c|c|c|c|}
\hline \multirow[b]{2}{*}{$\begin{array}{l}\text { Commodity } \\
\text { mineral }\end{array}$} & \multicolumn{6}{|c|}{ Setores } & \multirow[b]{2}{*}{$\begin{array}{l}\text { Principal } \\
\text { produtor }\end{array}$} & \multirow[b]{2}{*}{$\begin{array}{l}\text { Principal } \\
\text { fornecedor }\end{array}$} & \multirow[b]{2}{*}{$\begin{array}{l}\text { Principais exemplos de } \\
\text { aplicação }\end{array}$} \\
\hline & 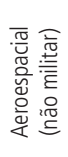 & 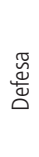 & 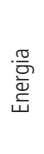 & 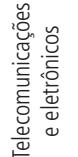 & 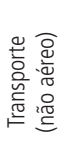 & $\begin{array}{l}\text { 气 } \\
\stackrel{5}{5} \\
0\end{array}$ & & & \\
\hline
\end{tabular}

\begin{tabular}{|c|c|c|c|c|c|c|c|c|c|}
\hline Alumínio & $x$ & $x$ & $x$ & $x$ & $x$ & $x$ & China & Canadá & $\begin{array}{l}\text { Aeronaves, linhas de transmissão } \\
\text { de energia, ligas leves }\end{array}$ \\
\hline Antimônio & - & $x$ & $x$ & $x$ & $x$ & $x$ & China & China & Baterias de chumbo-ácido \\
\hline Arsênio & - & $x$ & $x$ & $x$ & - & $x$ & China & China & $\begin{array}{l}\text { Comunicações (arsenieto } \\
\text { de gálio) }\end{array}$ \\
\hline Barita & - & - & $x$ & $x$ & - & $x$ & China & China & $\begin{array}{l}\text { Fluido de perfuração de } \\
\text { petróleo e gás }\end{array}$ \\
\hline Berílio & $x$ & $x$ & $x$ & $x$ & - & $x$ & $\begin{array}{l}\text { Estados } \\
\text { Unidos }\end{array}$ & Cazaquistão & $\begin{array}{l}\text { Comunicações por } \\
\text { satélite, metal berílio para } \\
\text { indústria aeroespacial }\end{array}$ \\
\hline Bismuto & - & $x$ & $x$ & $x$ & - & $x$ & China & China & $\begin{array}{l}\text { Produtos farmacêuticos, soldas } \\
\text { sem chumbo }\end{array}$ \\
\hline $\begin{array}{l}\text { Césio e } \\
\text { rubídio }\end{array}$ & $x$ & $x$ & $x$ & $x$ & - & $x$ & Canadá & Canadá & $\begin{array}{l}\text { Aplicações médicas, satélites } \\
\text { de posicionamento global, } \\
\text { dispositivos de visão noturna }\end{array}$ \\
\hline Cromo & $x$ & $x$ & $x$ & $x$ & $x$ & $x$ & $\begin{array}{l}\text { África do } \\
\text { Sul }\end{array}$ & África do Sul & $\begin{array}{l}\text { Motores a jato (superligas), } \\
\text { aços inoxidáveis }\end{array}$ \\
\hline Cobalto & $x$ & $x$ & $x$ & $x$ & $x$ & $x$ & Congo $^{1}$ & Noruega & $\begin{array}{l}\text { Motores a jato (superligas), } \\
\text { baterias recarregáveis }\end{array}$ \\
\hline Flúor & - & - & $x$ & $x$ & - & $x$ & China & México & $\begin{array}{l}\text { Produção de alumínio e aço, } \\
\text { processamento de urânio }\end{array}$ \\
\hline Gálio & $x$ & $x$ & $X$ & $x$ & - & $x$ & China & China & $\begin{array}{l}\text { Radar, diodos emissores de luz } \\
\text { (light-emitting diodes - LEDs), } \\
\text { telefones celulares }\end{array}$ \\
\hline Germânio & $x$ & $x$ & $x$ & $x$ & - & $x$ & China & China & $\begin{array}{l}\text { Dispositivos infravermelhos, } \\
\text { fibra óptica }\end{array}$ \\
\hline $\begin{array}{l}\text { Grafita } \\
\text { (natural) }\end{array}$ & $x$ & $x$ & $x$ & $x$ & $x$ & $x$ & China & China & $\begin{array}{l}\text { Baterias recarregáveis, } \\
\text { armadura corporal }\end{array}$ \\
\hline Hélio & - & - & - & $x$ & - & $x$ & $\begin{array}{l}\text { Estados } \\
\text { Unidos }\end{array}$ & Qatar & $\begin{array}{l}\text { Criogenia (imagem por } \\
\text { ressonância magnética } \\
\text { [magnetic resonance } \\
\text { imaging - MRI]) }\end{array}$ \\
\hline Índio & $x$ & $x$ & $x$ & $x$ & - & $x$ & China & Canadá & $\begin{array}{l}\text { Monitores de tela plana (óxido } \\
\text { de índio-estanho), ligas especiais }\end{array}$ \\
\hline Lítio & $x$ & $x$ & $x$ & $x$ & $x$ & $x$ & Austrália & Chile & $\begin{array}{l}\text { Baterias recarregáveis, ligas } \\
\text { de alumínio-lítio para a } \\
\text { indústria aeroespacial }\end{array}$ \\
\hline Magnésio & $x$ & $x$ & $x$ & $x$ & $x$ & $x$ & China & China & $\begin{array}{l}\text { Segurança de incêndio para } \\
\text { indústria aeroespacial }\end{array}$ \\
\hline Manganês & $x$ & $x$ & $x$ & $x$ & $x$ & $x$ & China & África do Sul & $\begin{array}{l}\text { Produção de alumínio e aço, } \\
\text { ligas leves }\end{array}$ \\
\hline
\end{tabular}


(Continuação)

\begin{tabular}{|c|c|c|c|c|c|c|c|c|c|}
\hline \multirow[b]{2}{*}{$\begin{array}{l}\text { Commodity } \\
\text { mineral }\end{array}$} & \multicolumn{6}{|c|}{ Setores } & \multirow[b]{2}{*}{$\begin{array}{l}\text { Principal } \\
\text { produtor }\end{array}$} & \multirow[b]{2}{*}{$\begin{array}{l}\text { Principal } \\
\text { fornecedor }\end{array}$} & \multirow[b]{2}{*}{$\begin{array}{l}\text { Principais exemplos de } \\
\text { aplicação }\end{array}$} \\
\hline & 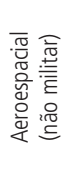 & $\frac{\widetilde{\pi}}{\stackrel{\tilde{N}}{\Delta}}$ & : & 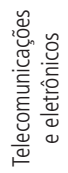 & 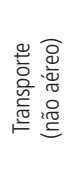 & $\stackrel{\text { o }}{\frac{n}{5}}$ & & & \\
\hline Nióbio & $x$ & $x$ & $x$ & $x$ & - & $x$ & Brasil & Brasil & $\begin{array}{l}\text { Aço de alta resistência para } \\
\text { defesa e infraestrutura }\end{array}$ \\
\hline $\begin{array}{l}\text { Metais } \\
\text { do grupo } \\
\text { platina² }\end{array}$ & $x$ & - & $x$ & $x$ & $x$ & $x$ & $\begin{array}{l}\text { África do } \\
\text { Sul }\end{array}$ & África do Sul & $\begin{array}{l}\text { Catalisadores, superligas para } \\
\text { motores a jato }\end{array}$ \\
\hline Potássio & - & - & $x$ & $x$ & - & $x$ & Canadá & Canadá & Fertilizante agrícola \\
\hline $\begin{array}{l}\text { Elementos } \\
\text { terras } \\
\text { raras }^{3}\end{array}$ & $x$ & $x$ & $x$ & $x$ & $x$ & $x$ & China & China & $\begin{array}{l}\text { Orientação aeroespacial, lasers, } \\
\text { fibra óptica }\end{array}$ \\
\hline Rênio & $x$ & - & $x$ & $x$ & - & $x$ & Chile & Chile & $\begin{array}{l}\text { Motores a jato } \\
\text { (superligas), catalisadores }\end{array}$ \\
\hline Escândio & $x$ & $x$ & $x$ & $x$ & - & $x$ & China & China & $\begin{array}{l}\text { Ligas leves, células } \\
\text { de combustivel }\end{array}$ \\
\hline Estrôncio & $x$ & $x$ & $x$ & $x$ & $x$ & $x$ & Espanha & México & $\begin{array}{l}\text { Ligas de alumínio, ímãs } \\
\text { permanentes, flares }\end{array}$ \\
\hline Tântalo & $x$ & $x$ & $x$ & $x$ & - & $x$ & Ruanda & China & $\begin{array}{l}\text { Capacitores em telefones } \\
\text { celulares, motores a } \\
\text { jato (superligas) }\end{array}$ \\
\hline Telúrio & - & $x$ & $x$ & $x$ & - & $x$ & China & Canadá & $\begin{array}{l}\text { Dispositivos infravermelhos } \\
\text { (visão noturna), células solares }\end{array}$ \\
\hline Estanho & - & $x$ & - & $x$ & - & $x$ & China & Peru & $\begin{array}{l}\text { Solda, monitores de tela plana } \\
\text { (óxido de índio-estanho) }\end{array}$ \\
\hline Titânio & $x$ & $x$ & $x$ & $x$ & - & $x$ & China & África do Sul & $\begin{array}{l}\text { Motores a jato (superligas) e } \\
\text { fuselagens (ligas de titânio), } \\
\text { aço de alta resistência }\end{array}$ \\
\hline Tungstênio & $x$ & $x$ & $x$ & $x$ & - & $x$ & China & China & $\begin{array}{l}\text { Ferramentas de corte e } \\
\text { perfuração, catalisadores, } \\
\text { motores a jato (superligas) }\end{array}$ \\
\hline Urânio & $x$ & $x$ & $x$ & - & - & $x$ & Cazaquistão & Canadá & $\begin{array}{l}\text { Aplicações nucleares, } \\
\text { aplicações médicas }\end{array}$ \\
\hline Vanádio & $x$ & $x$ & $x$ & $x$ & - & $x$ & China & África do Sul & $\begin{array}{l}\text { Motores a jato (superligas) e } \\
\text { fuselagens (ligas de titânio), } \\
\text { aço de alta resistência }\end{array}$ \\
\hline $\begin{array}{l}\text { Zircônio e } \\
\text { háfnio }\end{array}$ & $x$ & $x$ & $x$ & $x$ & - & $x$ & Austrália & China & $\begin{array}{l}\text { Revestimento de barreira } \\
\text { térmica em motores a jato, } \\
\text { aplicações nucleares }\end{array}$ \\
\hline
\end{tabular}

Fonte: USGS (2019).

Notas: ${ }^{1}$ República Democrática do Congo.

${ }^{2}$ Esta categoria inclui platina, paládio, ródio, rutênio, irídio e ósmio.

${ }^{3}$ Esta categoria inclui o ítrio e os lantanídeos. [X, setor aplicável; -, não aplicável] 


\subsection{República Popular da China}

A China tem promovido uma estratégia historicamente protecionista em favor de seus recursos minerais, favorecendo a sua indústria doméstica. Este processo, iniciado em 1950, buscou inicialmente a ampliação da mineração chinesa no interior da Mongólia, em depósitos de ferro, por meio da Companhia de Ferro e Aço de Baotou (Barteková e Kemp, 2016). O exemplo mais notável do domínio chinês no mercado mundial se dá no segmento dos elementos de terras raras. $\mathrm{Na}$ década de 1990, a partir do empreendimento de novos métodos extrativos e investimentos em pesquisa e inovação tecnológica, o governo chinês previu sua alavancada econômica com base na utilização dos seus recursos minerais, através do plano nacional de desenvolvimento de alta tecnologia (BaoTou Development Zone, 2015), sobre o qual o estrategista chinês, primeiro-ministro Deng Xiaoping, comentou em 1992, em tradução nossa: "existe petróleo no Oriente Médio e existem terras raras na China” (Uren, 2019). Seu destaque como principal fornecedor de terras raras, bens minerais vitais para a construção de dispositivos essenciais para equipamentos eletroeletrônicos e de energia renovável, elevou a China ao patamar de um dos principais inovadores em tecnologia digital (Mancheri, Sundaresan e Chandrashekar, 2013).

Em 2009, a China detinha 98\% do total do mercado mundial de terras raras (USGS, 2015) e seu poderio quase monopolista foi atribuído à sua barata mão de obra e aos custos regulatórios menores, que contribuíram para os baixos preços de seus minerais e a diminuição de participação do resto do mundo neste segmento (Haxel, Hedrick e Orris, 2002). Contudo, a China não se especializou somente na produção mineral voltada para exportação, investindo consistentemente, desde meados do século XX, em P\&D de tecnologias, com foco no seu desenvolvimento industrial (Barteková e Kemp, 2016). Sua liderança ampla no segmento de terras raras advém dos esforços em P\&D associados a indústria (Shen, Moomy e Eggert, 2020).

Através das inúmeras iniciativas chinesas em pesquisa, desenvolvimento e inovação (PD\&I), a gradual mudança do perfil do exportador mineral foi estrategicamente planejada na direçấo da exportação de produtos intermediários, com maior valor agregado, e também através da transferência de tecnologia com base no investimento direto em países produtores, entre eles o Brasil.

Com a finalidade de proteger suas reservas de terras raras em crescente disputa mundial e garantir a crescente evolução da demanda de sua indústria, a China declarou as terras raras como "minerais estratégicos e protegidos" (SCIO, 2012), pactuando políticas de proteção especialmente voltadas para as reservas minerais, em conjuntoe com planos de ação nacionais para a exploração de seus recursos minerais, que envolviam licenciamento das empresas produtoras, 
políticas de eficiência extrativa e ambiental, transparência comercial das empresas mineradoras e regulações de cotas de exportação (Pothen e Fink, 2015).

Estas políticas industriais chinesas revelam o firme interesse em garantir a dominação neste segmento do mercado, através da criação de vantagens competitivas para suas indústrias e controle do comércio destinado à exportação, garantindo preços competitivos no mercado mundial (Shen, Moomy e Eggert, 2020). Estas medidas conduziram a uma disputa entre os Estados Unidos, a União Europeia, o Japão e outros países, que, devido às restriçốes chinesas impostas principalmente para as exportaçôes de elementos de terras raras, tungstênio e molibdênio, apresentaram uma reclamação de violação de conduta na Organização Internacional do Comércio (OMC).

Em resposta a esta reclamação, o Ministério do Comércio da China defendeu sua política de exportação, alegando que as suas cotas de exportação seriam justas porque, em essência, buscavam proteger o meio ambiente e a sustentabilidade dos recursos minerais, alegando que os interesses dos países ocidentais tencionavam pressionar a China na produçáo barata e em larga escala de elementos de terras raras, sem uma preocupação com os sérios problemas ambientais do país (Pothen e Fink, 2015).

O julgamento da disputa através da GATT/WTO foi contrário à China, que oficialmente aboliu as cotas de exportação em 1o de janeiro de 2015. Entretanto, esta decisão culminou em uma nova fase de políticas regulatórias para os elementos de terras raras na China, que passou a regular sobre as suas práticas domésticas, em vez de incidir sobre o comércio internacional (Shen, Moomy e Eggert, 2020). As políticas regulatórias chinesas adotaram açôes para fortalecer o licenciamento das empresas mineradoras, com fortes critérios ambientais e combatendo a mineração ilegal, objetivando, por fim, o fortalecimento das empresas chinesas com melhor performance, em especial as empresas governamentais.

Deve-se destacar que, além de uma política mineral baseada em extenso controle e licenciamento, a China evoluiu em sua política mineral, tanto como grande fornecedora - a exemplo do caso das terras raras - como importante produtora de manufaturados. A China é uma das maiores importadoras de bens minerais, e busca estreitar laços comerciais na indústria extrativa mineral de países ricos em recursos minerais, como é o caso do nióbio no Brasil. Com políticas de agregação de valor focadas na produção de bens minerais semimanufaturados e produtos finais, a China busca garantir o suprimento dos minerais menos disponíveis em seu território pela aquisição de posiçóes em empresas e negócios em várias partes do mundo.

No tocante às relações da China com o Brasil, um exemplo desta dinâmica é o caso dos minérios de nióbio, no qual a estratégia chinesa foi adquirir a empresa 
Niobras, mineradora e produtora de ferronióbio instalada em Ouvidor-GO, através da empresa China Molybdenum Corporation (CMOC). A seguir, será discutido o desenvolvimento das políticas regulatórias do setor mineral brasileiro na interface com a questão dos minerais estratégicos.

\subsection{Brasil}

O Brasil é reconhecidamente um produtor líder e atuante no mercado global de commodities minerais, em especial dos metálicos. O país também conta com estratégias definidas para a exploração dos seus recursos minerais, o que pode ser observado em dois documentos estratégicos definidos pelo Poder Executivo: o Plano Nacional de Mineraçấo (PNM) 2030 (MME, 2010); e a Estratégia Nacional de Ciência e Tecnologia 2016-2022 (MCTIC, 2016).

No PNM 2030, entre os objetivos estratégicos definidos, encontra-se a Gestâo de Minerais Estratégicos, definidos como um conjunto de bens minerais constituídos por:

1) Minerais que o país importa em grande escala, como potássio, fosfato, carvão mineral metalúrgico e aqueles para os quais há possibilidade de importação em futuro próximo, como o urânio.

2) Minerais cuja demanda é crescente e que deverá se expandir ainda mais nas próximas décadas, por causa do uso em produtos de alta tecnologia, a exemplo das terras raras, lítio, tântalo, térbio e cobalto.

3) Minerais em que o Brasil apresenta vantagens comparativas naturais e conquistou liderança internacional, tais como o minério de ferro e o nióbio.

O PNM-2030 (MME, 2010) tem como base três diretrizes: governança pública, que é eficaz para a promoção do uso dos bens minerais da indústria extrativa nacional de interesse comercial; o estímulo à agregação de valor aos produtos minerais semimanufaturados e manufaturados; a ampliação do conhecimento científico e a sustentabilidade no setor mineral. As açóes sugeridas no documento são as seguintes:

- Criação de Grupos de Trabalho para acompanhamento de bens minerais estratégicos, com enfoque para as oportunidades e ameaças do mercado internacional.

- Articulação interministerial com o setor produtivo para elaboração de programas de longo prazo voltados aos minerais portadores de futuro, objetivando a interação entre Institutos de Ciência e Tecnologia (ICTs) e empresas, para a identificação de nichos competitivos de atuação. 
Em termos de articulação interministerial, houve concreta ação conjunta com o MCTI, no sentido de se atender à proposta do Ministério de Minas e Energia. A ligação entre os ministérios se encontra retratada no documento “Estratégia Nacional de Ciência e Tecnologia 2016-2020" (MCTIC, 2016), no qual duas estratégias foram formuladas.

1) Elaboração do Plano de Ação de Ciência, Tecnologia e Inovação para Minerais Estratégicos.

2) Fomentar a pesquisa, o desenvolvimento tecnológico e a inovação em minerais estratégicos, visando à produçáo de produtos finais baseados nesses elementos.

O Plano de Ação de Ciência, Tecnologia e Inovação para Minerais Estratégicos (MCTIC, 2018), elaborado pela entáo Secretaria de Desenvolvimento Tecnológico e Inovação do MCTIC, contemplou os minerais sugeridos no PNM 2030 e identificou desafios, com a proposição de metas e açôes. O foco do plano são os elementos de terras raras, minerais de lítio, silício e grafita, nomeados como minerais portadores de futuro; os agrominerais, em face da importância crescente do agronegócio no Brasil; e os minerais tais como os de nióbio e de ferro, devido a sua farta disponibilidade e à posição de liderança de empresas brasileiras no comércio internacional. Entre as sete estratégias de implementação citadas no plano, foi delineada a relevância da cooperação internacional, mencionando-se a manutenção das cooperaçôes existentes com a Alemanha e a União Europeia, bem como se propondo a expansão para outros países (MCTIC, 2018, p. 40).

Quanto ao fomento à PD\&I, açóes concretas também foram implementadas, como, por exemplo, a do Programa Inova Mineral, uma iniciativa do Banco Nacional de Desenvolvimento Econômico e Social (BNDES) e da Financiadora de Estudos e Projetos (Finep), que abriram edital conjunto para financiamento da ordem de $\mathrm{R} \$ 1,2$ bilhão (aproximadamente $€ 280$ milhóes) para planos de negócios de empresas envolvendo instituiçóes de pesquisa e ensino, mediante julgamento da submissão de propostas comprometidas com PD\&I no setor mineral brasileiro. Neste programa, entre outras prioridades, encontram-se mencionadas como de "grande interesse" as propostas sobre minerais portadores de futuro, sendo citados os minerais que contêm cobalto, grafita, lítio, metais do grupo da platina, molibdênio, silício (grau solar), tálio, tântalo, terras raras, titânio, vanádio e o nióbio. O Inova Mineral lançou um edital em 2017, tendo aprovado, numa primeira seleção, 24 planos de negócios no valor de R \$ 727 milhôes (Finep, 2017).

Em 2020, o Ministério de Minas e Energia (MME) lançou a publicação intitulada Programa Mineraçấo e Desenvolvimento 2020/2023, com o objetivo de identificar metas e açóes para a aceleraçáo da produção mineral brasileira, em alinhamento com o desenvolvimento sustentável em suas bases sócio-econômico-ambientais. 
O programa apresenta dez planos e 108 metas, divididas entre os temas: economia mineral, responsabilidade socioeconômica, conhecimento geológico, avanço da mineração em novas áreas, investimento no setor mineral, seleção de açóes futuras, governança na mineração, gestão e eficiência, combate às práticas ilícitas e mineração na sociedade (MME, 2020). Observa-se que a questáo dos minerais estratégicos e críticos foi contemplada no Programa 2020/2023 em apenas uma meta, todavia está indiretamente representada em metas associadas a aspectos geológicos e de pesquisa mineral.

O Brasil continua carecendo de estudos mais específicos sobre a criticalidade das matérias-primas importantes para a sua economia, tendo por base o consumo e demanda futura de insumos essenciais para a sua indústria, dentro da perspectiva de avaliação de riscos de suprimento, tanto doméstico, como por importaçôes. É importante distinguir as matérias-primas críticas das consideradas estratégicas, pois cada grupo requer políticas específicas para um aprimoramento integrado entre indústria extrativa e de transformação, bem como das políticas de comércio exterior, fomento à atividade industrial e à PD\&I.

A economia circular também é uma questão importante a ser explorada nas políticas públicas, pois tem consequências sobre a demanda por matérias-primas, e a produção mineral brasileira pode sofrer consequências negativas em suas projeçóes, levando-se em consideraçáo que qualquer projeto de engenharia mineral trabalha com fluxos de caixa para dezenas de anos. Nesta temática, o estudo desenvolvido pela Confederaçáo Nacional da Indústria (CNI), intitulado Economia circular: oportunidades e desafios para a indústria brasileira (CNI, 2018), apresenta modelos de negócios e aspectos facilitadores para estimular a adoção da economia circular na indústria brasileira.

Na próxima seção, serão abordados o estudo de caso do nióbio brasileiro e as relaçôes econômicas, corporativas e tecnológicas entre a China e o Brasil, procurando-se demonstrar que existem parcerias, complementariedades e aspectos que podem ser aprimorados nas relaçôes bilaterais.

\section{PARCERIAS E COMPLEMENTARIEDADES ENTRE BRASIL E CHINA E O CASO DO NIÓBIO}

Por que o Brasil comercializaria com um país como a China, do outro lado do mundo? Isso pode ser explicado pela chamada teoria gravitacional do comércio internacional (TGCI). O modelo gravitacional do comércio internacional, criado por Jan Tinbergen em 1962, é usado para estudar o tamanho dos fluxos de comércio bilateral entre quaisquer dois países, e pode ser resumido por uma "equação da gravidade", ou seja, assim como os planetas são atraídos em proporção ao seu tamanho e proximidade, os fluxos de comércio entre os países também o 
são: o tamanho relativo é determinado pelo produto interno bruto (PIB) e a proximidade econômica é determinada pelos custos de comércio. $\mathrm{O}$ modelo de gravidade do comércio internacional sugere que o tamanho econômico relativo atrai os países ao comércio uns com os outros, enquanto distâncias maiores enfraquecem a atratividade.

A TGCI pode explicar a importância mundial da China no comércio internacional, e não apenas nas relaçóes bilaterais com o Brasil. A China é atualmente o maior importador de commodities, e isso se deve ao fato de que seu crescimento econômico pujante, principalmente na indústria, demanda matérias-primas, semimanufaturados e fontes de energia dos outros países, por não dispor de todos os minérios de que necessita, além de possuir poucas reservas naturais de petróleo e gás natural.

O Brasil exporta para a China principalmente produtos básicos: grãos, produtos da pecuária, minério de ferro e petróleo. A China exporta para o Brasil principalmente produtos manufaturados (mais de $90 \%$ do que foi importado da China), como anteriormente apresentado na tabela 2. É importante ressaltar que, em decorrência das especificidades das relaçóes bilaterais Brasil-China, torna-se urgente a adoção de políticas que reforcem a competitividade estrutural da indústria brasileira. Nas palavras de Hiratuka e Sarti (2016), in verbis: "deve-se lembrar que o tamanho e o dinamismo do mercado chinês têm deslocado as escalas de produção para níveis extremamente elevados; fato esse que proporciona vantagens de custo que se somam aos custos de mão de obra”.

A China se destaca como um dos maiores consumidores mundiais de matérias-primas críticas, especializando-se na aplicação de suas propriedades especiais através da pesquisa e inovaçáo e de uma longa trajetória de investimentos em sua indústria doméstica, para uma produção com maior valor agregado destinada à exportaçấo. Com base em uma política que pode ser considerada protecionista de suas principais reservas minerais, a política mineral chinesa tem provocado tensóes diplomáticas com outros países e bloco de países que demandam por insumos.

Em relação ao setor mineral, Brasil e China têm estratégias diversas quanto ao uso e a potencialização dos benefícios de seus recursos naturais, todavia se tornaram complementares e importantes para ambos em alguns casos, como o do nióbio. O Brasil tem posição destacada quanto a reservas e produção de minérios contendo nióbio em seus minerais mais utilizados, o pirocloro e a columbita-tantalita, bem como é o principal beneficiador, fabricante e exportador mundial de produtos intermediários contendo nióbio, em especial de ligas metálicas destinadas à siderurgia, com destaque para a liga ferronióbio. Os principais segmentos industriais consumidores de ferroligas estâo apresentados no gráfico 4 . 


\section{GRÁFICO 4}

Mercado mundial para ferroligas com nióbio, de acordo com as suas aplicações em aços (Em \%)



Estrutural

Automotivo

Outros

Fonte: CBMM (2018).

Outros semimanufaturados de nióbio são insumos de maior valor agregado e se prestam a aplicaçóes muito úteis ou essenciais a uma sociedade cada vez mais interligada pelas telecomunicaçóes e sistemas digitais, tais como:

- óxidos de nióbio em dispositivos óticos e eletrônicos, a exemplo do composto niobato de lítio destinado às telecomunicaçóes, empregado tanto em dispositivos capacitores como em moduladores, transformando sinais elétricos em óticos de amplo uso em celulares e nos sistemas de fibras óticas;

- a liga níquel-nióbio, destinada a ligas especiais (superligas) para turbinas de avióes e outros equipamentos de defesa, bem como utilizada em aços inoxidáveis;

- o nióbio metálico, do qual são produzidas as ligas supercondutoras utilizadas em equipamentos de diagnóstico do tipo ressonância magnética nuclear; e

- $\quad$ aplicaçóes em catalisadores de processos químicos a partir de compostos químicos de nióbio.

Embora sejam base para cadeias de valor importantes, as quantidades utilizadas de nióbio são muito reduzidas, bem como os valores totais auferidos no mercado destes insumos intermediários. As receitas da principal empresa produtora, a Companhia Brasileira de Metalurgia e Mineração (CBMM), demonstram que o faturamento com 
ferronióbio continua rentável e diversificado, como ilustra o gráfico 5 . As empresas de alta capacidade tecnológica desfrutam de maiores vantagens, por atuarem no processamento dessas especialidades. Nesses mercados, a China se encontra muito bem posicionada e suas empresas investem em vários segmentos de inovação.
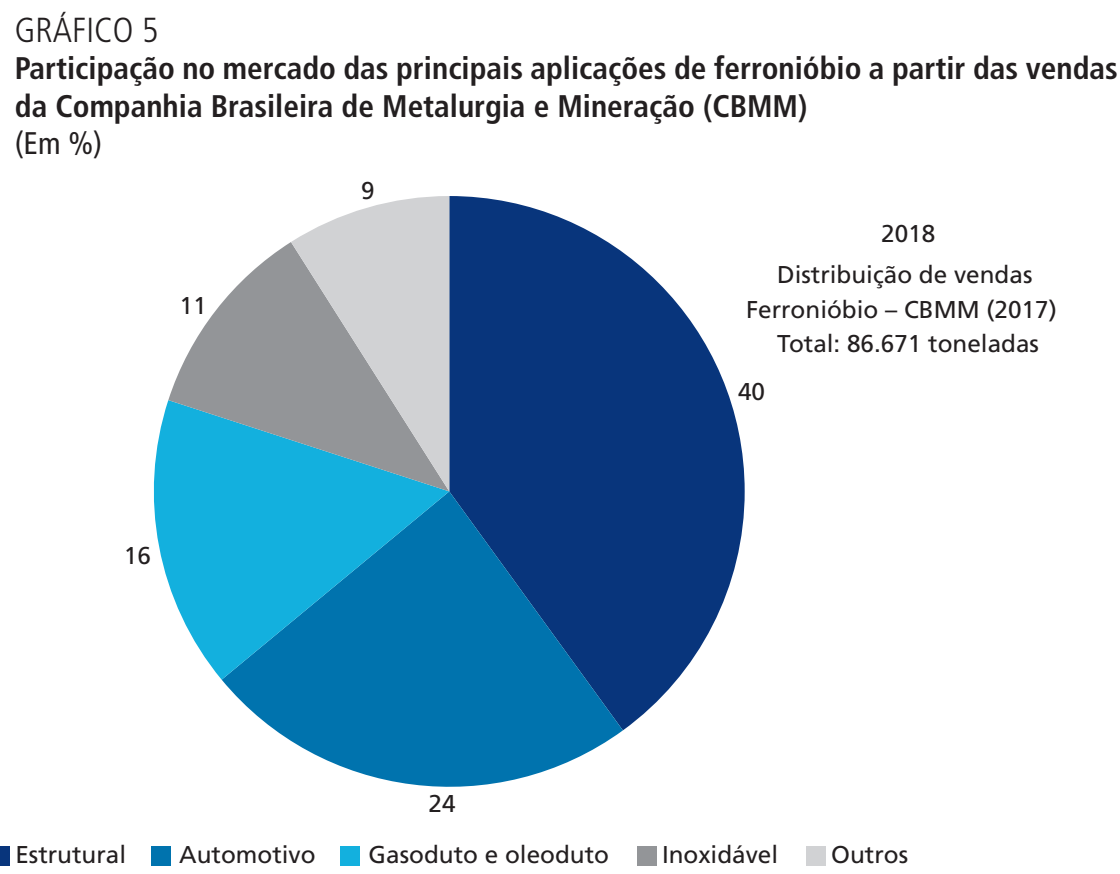

Fonte: CBMM (2018).

Face às proporções limitadas em massa de nióbio que são utilizadas nos produtos finais, observa-se que a demanda mundial se encontrava na escala anual inferior a 100 mil toneladas de nióbio contido, antes da pandemia de Covid-19. Mesmo assim, como visto anteriormente, o nióbio é considerado uma matéria-prima crítica por vários países, pois o seu fornecimento está limitado a praticamente dois países: Brasil e Canadá.

As principais empresas mineradoras, seus produtos beneficiados e semimanufaturados, localizadas no Brasil são a CBMM, que opera a Companhia Mineradora do Pirocloro de Araxá (Comipa), uma associação da própria CBMM com a Companhia de Desenvolvimento Econômico de Minas Gerais (Codemig); a Niobras, ligada a CMOC Internacional; a Mineraçáo Taboca, controlada pelo grupo minerador peruano Minsur; e a Niobec, empresa com sede na província de Quebec, no Canadá. Todas estas empresas realizam operaçóes metalúrgicas e/ou de processamento químico para oferecer 
os produtos discriminados no quadro 1 , que apresenta as principais empresas e seus produtos.

QUADRO 1

Principais empresas mineradoras e produtoras de semiacabados que contêm nióbio

\begin{tabular}{|l|l|}
\hline & $\begin{array}{l}\text { Ferronióbio stand. ou FeNb } \\
\text { FeNb e NiNb (níquel-nióbio) grau vácuo } \\
\text { Óxidos: alta pureza, grau ótico, ácido nióbico (HY-340) e oxalato } \\
\text { amoniacal de nióbio (ANO) } \\
\text { Nióbio metálico: grau reator, grau comercial, RRR grau supercondutor } \\
\text { eliga zircônio-nióbio }\end{array}$ \\
\hline
\end{tabular}

Fonte: Diálogos Setoriais UE-Brasil (2020).

A participação da China em negócios ligados ao nióbio se elevou em 2016, quando a empresa CMOC adquiriu as operaçóes de fosfatos e nióbio da empresa Anglo American localizadas em Goiás, nos municípios de Catalão e Ouvidor. Além de se tornar a segunda maior produtora de fosfato e fertilizantes do Brasil através da Copebras, a CMOC se tornou a segunda maior produtora de ferronióbio mundial. A CBMM também conta com presença de capital chinês desde 2011, quando um consórcio formado por cinco empresas adquiriu 15\% da participação na empresa (Ribeiro e Maia, 2011). Por fim, observa-se que a China tem aumentado o uso de aços conhecidos, como aços de alta resistência e baixa liga (ARBL), em estruturas da construção civil, o que elevou o consumo de alguns elementos de liga, entre estes o nióbio.

Cabe destacar que se observa importante investimento em várias naçóes no segmento de inovaçóes de produtos e/ou processos em que o nióbio é componente essencial, ou mesmo subsidiário, para obter propriedades e características inovadoras ou para reduzir custos de produção. No caso brasileiro, a empresa CBMM atualmente participa em consórcios de pesquisa internacionais que podem abrir mercados muito interessantes, alguns com empresas chinesas de metalurgia, bem como com japonesas, o que ocorre no caso de baterias para veículos elétricos e outras aplicações (CBMM, 2018). 
No estudo realizado pelo Cetem/MCTI (Diálogos Setoriais UE-Brasil, 2020) sobre a cadeia produtiva do nióbio, revelou-se que a China está à frente na pesquisa e na inovação no que se refere a nióbio, considerando-se a produção de artigos científicos e de pedidos de patente. Os gráficos 6 e 7 indicam a liderança da China na busca de inovaçóes no período estudado, em vários campos de aplicaçáo do nióbio. A pesquisa realizada no Brasil ainda participa com poucas inovações nesse cenário.

GRÁFICO 6

Patentes do requisitante relacionadas a aços inox, aços, ligas e catalisadores, por país de origem (2013-2017)



Fonte: Diálogos Setoriais UE-Brasil (2020).

Obs.: Gráfico cujos leiaute e textos não puderam ser padronizados e revisados em virtude das condições técnicas dos originais (nota do Editorial).

\section{GRÁFICO 7}

Patentes do requisitante relacionadas a especialidades e dispositivos portadores de nióbio, por país de origem (2013 a 2017)

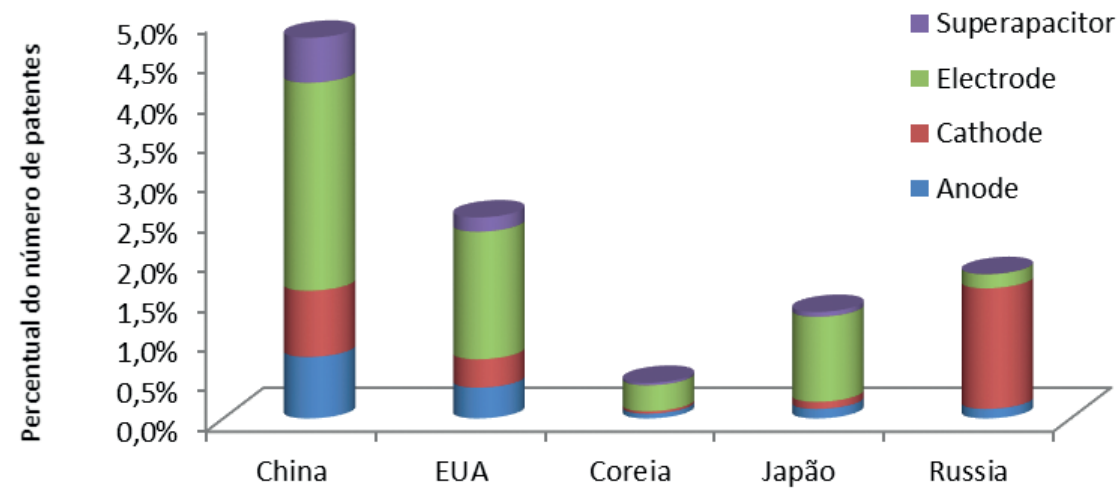

Fonte: Diálogos Setoriais UE-Brasil (2020).

Obs.: Gráfico cujos leiaute e textos não puderam ser padronizados e revisados em virtude das condições técnicas dos originais (nota do Editorial). 
A constatação de várias parcerias nos negócios e nas tecnologias do nióbio é todavia uma exceção, dado que as participaçôes em consórcios de pesquisa entre Brasil e os demais países do bloco BRICS (Brasil, Rússia, Índia, China e África do Sul) permanecem inferiores aos verificados em outros países e blocos, a exemplo dos países da Uniáo Europeia, tal como apresentado em recente estudo do Ipea (Kubota, 2020). No entanto, o mesmo não ocorre no caso do nióbio, pois a CBMM brasileira mantém estreitas relaçóes com centros de pesquisa na China há quarenta anos, o que tem permitido a ampliação de aplicaçóes do nióbio e, por conseguinte, aumento de seu mercado (CBMM, 2020).

Deve-se destacar que a Ordem Executiva no 13.953 de 20 de setembro de 2020 do governo dos Estados Unidos sugere açóes no sentido de reduzir a dependência de importação de minerais críticos, explicitamente citando o caso de diversos minerais advindos da China, ressaltando sua estratégia econômica, considerada agressiva e que explora vantagens competitivas no mercado "através de restrições internas e coação de empresas pela dependência de sua propriedade intelectual e tecnológica" (White House, 2020).

As balanças comerciais entre China e Brasil, no que concerne aos recursos minerais, demonstram que a China exporta produtos manufaturados e de maior valor agregado. O Brasil permanece na condição de fornecedor de bens minerais primários, o que garante um significativo superavit comercial ao país, mas sem se beneficiar desta vantagem competitiva ou destinando investimentos para a indústria doméstica.

\section{CONCLUSÕES}

A geopolítica das matérias-primas vem se reformulando rapidamente diante do cenário de disputas comerciais e por liderança econômica, acirradas pela necessidade de garantia de suprimentos, que se vê ameaçada pela concentraçâo da produção de insumos primários e intermediários em poucos países. Nesse cenário, as recentes políticas nacionais avaliadas da União Europeia, Estados Unidos, China e Brasil podem ser sinteticamente descritas, levando-se em consideração as características mencionadas a seguir.

\subsection{União Europeia}

Destaca-se pela abrangência de seus estudos conceituais e na abordagem de relaçóes diplomáticas mais amplas, estimulando a pesquisa e inovação, principalmente associada com aspectos de economia circular e reuso ou recuperação de matérias-primas críticas. 


\subsection{Estados Unidos}

A partir de levantamentos de suas capacidades e demandas industriais, bem como das reservas mundiais em produção, objetiva acompanhar o atendimento e alertar para riscos e ameaças à sua demanda doméstica, a partir do acompanhamento de suas principais aplicaçôes na indústria norte-americana. Ultimamente, vem focalizando o combate ao aumento da vulnerabilidade por conta da dependência de minerais críticos, citando em seus documentos vários países, e mais especificamente China, por ser a mais importante fornecedora. A estratégia estadunidense prioriza investimentos em exploração mineral e em pesquisa e inovação de processos e produtos.

\subsection{China}

Apresenta uma política - que pode ser considerada protecionista - de suas reservas minerais, sobre algumas das quais detém grande vantagem competitiva entre os demais produtores no mundo, priorizando uma estratégia de fortalecimento de sua economia com base na agregação de valor aos produtos que destina à exportação. Especializou-se como fornecedora de matérias-primas e especialmente de insumos essenciais para várias cadeias de produção mundiais - por exemplo, da saúde e de tecnologias voltadas para as energias renováveis, neste último caso devido a seu grande domínio no mercado de elementos de terras raras. A China também se destaca como um dos maiores consumidores mundiais de matérias-primas críticas, o que, combinado a uma política protecionista de suas reservas minerais, vem provocando tensões diplomáticas, que se verificam através de imposição de barreiras ao comércio pelos aumentos de taxação e/ou pela adoção de cotas de importação.

\subsection{Brasil}

Evidencia-se como importante fornecedor mundial de commodities e de algumas especialidades minerais, concentrando participaçóes expressivas nas reservas mundiais de diversas matérias-primas minerais, com destaque para o nióbio, entre as matérias-primas julgadas críticas tanto pela União Europeia como pelos Estados Unidos. A estratégia da política mineral brasileira tem buscado ampliar parcerias e estimular o desenvolvimento tecnológico e a pesquisa mineral; contudo, diante do panorama mundial observado neste tema, o Brasil carece de estudos sobre as suas cadeias produtivas, para uma definição de criticalidade de bens minerais e planejamento do suprimento e desenvolvimento das cadeias produtivas nacionais.

As políticas sobre matérias-primas que passaram a definir um grupo de minerais como críticos têm sido atualizadas tanto pela Uniáo Europeia quanto pelos Estados Unidos, revelando a preocupação com a dependência de fornecimento a partir da China, e de outros países, entre eles o Brasil no caso do nióbio. Recentemente, em 2020, foram publicadas novas listas de matérias-primas críticas pela União Europeia (EC, 2020) e pelos Estados Unidos (USGS, 2020). 
Os riscos de suprimento poderão provocar a busca de fornecedores alternativos ou mesmo a substituição de algumas matérias-primas em certas aplicaçôes em que isto for possível, como indicam as recentes políticas europeias e estadunidenses. A China se beneficiou enormemente de sua estratégia de suprimento doméstico e desenvolvimento industrial, bem como das participaçóes adquiridas em empresas localizadas em países produtores de matérias-primas escassas em seu território. Contudo, no caso brasileiro, a desvalorização do preço das commodities minerais e o baixo volume de investimentos na indústria nacional são pistas de vulnerabilidades às quais o Brasil está exposto, diante da continuidade das estratégicas internacionais que almejam outras rotas de suprimento, alternativas tecnológicas e aquisição de participação em empresas produtoras.

No quadro da importante relação comercial e corporativa entre Brasil e China, o setor mineral e metalúrgico se destaca, com ótimos resultados para ambos os países. O Brasil desfruta de bom superavit como exportador de bens primários, enquanto a China conta com suprimentos por meio de parcerias confiáveis e bem estabelecidas, como as que mantém com as empresas brasileiras Vale e CBMM.

No caso do nióbio, o interesse da China se ampliou com a aquisição da segunda maior mina do mundo, localizada no Brasil, ao passo que ratifica sua política de garantir o suprimento de matérias-primas consideradas essenciais para suas indústrias. A se julgar pela quantidade de pesquisas e de pedidos de patentes, o desempenho da China também evidencia um aumento da importância do nióbio em vários segmentos tecnológicos, embora as principais inovaçôes ainda estejam ligadas à metalurgia.

No contexto de oportunidades nas relaçóes entre China e Brasil que se mostram favoráveis, há grande espaço para uma ampliação das relaçóes entre os países pela colaboração em ciência e tecnologia, tanto na área mineral como nas aplicaçôes em produtos de alto conteúdo tecnológico, adotando-se como exemplo o caso bem-sucedido do nióbio. Por sua vez, o Brasil pode se inspirar na longa tradição de políticas com a União Europeia e os Estados Unidos para aprimorar as suas estratégias internas e relaçóes comerciais com os demais países importadores, levando em consideração também a garantia de suprimento para a indústria nacional dos bens minerais críticos para o país.

\section{REFERÊNCIAS}

ANM - AGÊNCIA NACIONAL DE MINERAÇÃO. Sumário Mineral 2017. Brasília: ANM. 2019.

Anuário Mineral Brasileiro 2019: principais substâncias metálicas. Ano base: 2018. Brasília: ANM. 2020. 
BAOTOU DEVELOPMENT ZONE. Rare earth: An introduction. Baotou National Rare Earth Hi-Tech Industrial Development Zone, 2015. Disponível em: <https://bit.ly/3aF4qIp>. Acesso em: 11 ago. 2020.

BARTEKOVÁ, E.; KEMP, R. Critical raw material strategies in different world regions. Maastricht: UNU-MERIT, 2016. (Working Paper Series). Disponível em: <https://bit.ly/3ueZmC3>. Acesso em: 22 jan. 2019.

BGS - BRITISH GEOLOGICAL SURVEY. Critical Raw Materials. Minerals UK, 2017. Disponível em: <https://bit.ly/3k3UJGl>. Acesso em: 11 mai. 2020. CBMM - Companhia Brasileira De Metalurgia E Mineração. Relatório de Sustentabilidade 2018. Araxá: CBMM. 2018.

. Nossa história. CBMM, 2020. Disponível em: <https://bit. ly/3bkutDM>. Acesso em: 20 nov. 2020.

CNI - CONFEDERAÇÃO NACIONAL DA INDÚSTRIA. Economia circular: oportunidades e desafios para a indústria brasileira. Brasília: CNI, 2018. DELOITTE SUSTAINABILITY et al. Study on the review of the list of critical raw materials. Bruxelas: EU publications, jun. 2017. Disponível em: <https:// bit.ly/3bijje0>.Acesso em: 28 jun. 2019.

DIÁLOGOS SETORIAIS UE-BRASIL. Estudo das cadeias produtivas dos materiais críticos: oportunidades e ameaças da economia circular. Cetem.gov, 2020. (Relatório Técnico Final). No prelo.

EC - EUROPEAN COMMISSION. The raw materials initiative-meeting our critical needs for growth and jobs in Europe. EU, 2008.

. Policy and strategy for raw materials. EC, 2017. Disponível em: <https:// bit.ly/3u9ahgJ>. Acesso em: 30 mar. 2019.

. Critical Raw Materials: Internal Market, Industry, Entrepreneurship and SMEs. EC, 2018. Disponível em: <https://bit.ly/3aFalgB>. Acesso em: 10 maio 2020.

Recovery of critical and other raw materials from mining waste and landfills. Sevilla: Joint Research Centre, 2019.

Study on the EU's list of Critical Raw Materials (2020). Brussels: EC, 2020. (Final report). Disponível em: <https://bit.ly/3s96JsT >. Acesso em: 20 nov. 2020.

FINEP - FINANCIADORA DE INOVAÇÃO E PESQUISA. Inova Mineral: plano de desenvolvimento, sustentabilidade e inovação no Setor de Mineração e Transformação Mineral. Finep, 2017. Disponível em: <https://bit.ly/3sekUNx>. Acesso em: 23 jan. 2019. 
FORTIER, S. M. et al. Draft critical mineral list - Summary of methodology and background information. USGS, 2019. (USGS technical input document in response to Secretarial Order, n. 3359).

HAXEL, G. B.; HEDRICK, J. B.; ORRIS, G. J. Rare earth elements - Critical resources for high technology. USGS, 2002. Disponível em: <https://on.doi. gov/37w5SdT>. Acesso em: 10 ago. 2020.

HIRATUKA, C.; SARTI, F. Relações econômicas entre brasil e china: análise dos fluxos de comércio e investimento direto estrangeiro. Revista Tempo do Mundo, v. 2, n. 1, jan. 2016 .

IRTC - INTERNATIONAL ROUND TABLE ON MATERIALS CRITICALITY. Material criticality: an overview for decision-makers.[s.l.]: EC; IRTC, 2020. No prelo.

KUBOTA, L. C. BRICS cooperation and science, technology and innovation: progress to be shown. Revista Tempo do Mundo, v. 22, p. 95-110, abr. 2020.

MANCHERI, N.; SUNDARESAN, L.; CHANDRASHEKAR, S. Dominating the world: China and the rare earth industry. Bangalore: National Institute of Advanced Studies, 2013. (Technical report). Disponível em: <https://bit. ly/3qI4P2k>. Acesso em: 10 ago. 2020.

MME - MINISTÉRIO DE MINAS E ENERGIA. Programa mineraçáo e desenvolvimento. Plano de metas e ações 2020/2023. Brasília: MME, 2020.

NSTC - NATIONAL SCIENCE AND TECHNOLOGY COUNCIL. Assessment of critical minerals: updated application of screening methodology. In: SUBCOMMITTEE ON CRITICAL AND STRATEGIC MINERAL SUPPLY CHAINS AND COMMITTEE ON ENVIRONMENT REPORT, NATURAL RESOURCES AND SUSTAINABILITY, 2018. Washington, D.C., United States. Anais... Washington: White House, Feb. 2018. Disponível em: $<$ https://bit.ly/37uN4Mc>. Acesso em: 22 jan. 2019.

POTHEN, F.; FINK, K. A political economy of China's export restrictions on Rare Earth Elements. Centre for European Economic Research. 2015. (Discussion paper, n. 15-025).

RIBEIRO, I.; MAIA, V. CBMM confirma venda de 15\% de seu capital para chineses. Valor Econômico, 1 set. 2011. Disponível em: <https://glo. bo/2ZwudMl>. Acesso em: 25 nov. 2020.

RMIS - RAW MATERIALS INFORMATION SYSTEM. Context. RMIS, 2015. Disponível em: <https://bit.ly/3k3xagI>. Acesso em: 20 jan. 2019. 
. What the JRC does. RMIS, 2017. Disponível em: <https://bit. ly/3boOp8f>. Acesso em: 20 jan. 2019.

ROLLAND, S. E. China-Raw Materials: WTO rules on Chinese Natural Resources export dispute. Insights, v. 16, n. 21, jun. 2012. Disponível em: $<$ https://bit.ly/3qB0n57>. Acesso em: 2 maio 2020.

SCIO - STATE COUNCIL INFORMATION OFFICE. Situation and policies of China's rare earth industries. Beijing: SCIO-China, 2012. Disponível em: <https://bit.ly/2M4ZN0w>. Acesso em: 20 ago. 2020.

SHEN, Y.; MOOMY, R.; EGGERT, R. G. China’s public policies toward rare earths, 1975-2018. Mineral Economics, v. 33, p. 127-151, 2020. Disponível em: <https://bit.ly/3uhKZwG>. Acesso em: 10 ago. 2020.

UREN, D. A quest for global dominance: China's appetite for rare earths. The strategist, 31 out. 2019. Disponível em: <https://bit.ly/2ZtDoNw>. Acesso em: 12 ago. 2020.

USDE - UNITED STATES DEPARTMENT OF ENERGY. Critical Materials Strategy. Department of Energy, dez. 2011. Disponível em: <https://bit. ly/3bf4cGE>. Acesso em: 13 ago. 2020.

USGS - UNITED STATES GEOLOGICAL SURVEY. Mineral commodity summaries - rare earths. US Department of Interior. 2015. Disponível em: $<$ http://minerals.usgs.gov/minerals/pubs/commodity/rare_earths/mcs-2015raree.pdf >. Acesso em: 10 ago. 2020.

. Use of raw materials in the United States from 1900 through 2014. USGS, 2017. Disponível em: <https://bit.ly/3kcqTQ8>. Acesso em: 20 abr. 2020. . Mineral Commodity Summaries 2019. Reston: USGS/USDI, 2019. Mineral Commodity Summaries. USGS, 2020. Disponível em: <https:// on.doi.gov/2Zwx1cl>. Acesso em: 2 ago. 2020.

WHITE HOUSE. Addressing the Threat to the Domestic Supply Chain from Reliance on Critical Minerals from Foreign Adversaries. Washington, D.C.: White House, 30 Sep. 2020. (Executive Order, n. 13.953). 